\title{
The Effect Of Building Block Game To The Ability Of Social Interaction Of Child With Autism Grade II
}

\author{
Tri Nuraini ${ }^{*}$, Abdul Salim $^{2}$, Mahardika Supratiwi $^{3}$ \\ 1,2, Pendidikan Luar Biasa, FKIP Universitas Sebelas Maret Surakarta, 57126, Indonesia
}

\begin{abstract}
The aim of this research is to know the effect of building block game to the ability of social interaction of child with autism grade II in SD Al Firdaus Surakarta in the year of 2018/2019. Research was using experimental approach single subject or known as single subject research (SSR) with A-B-A design. The result of the analysis showed the tendency of the direction and change of the level increased +1 at baseline-1 (A1), increased +4 at intervention (B), and constan $=0$ at baseline-2 (A2). High stability trend and overlap percentage $0 \%$. In baseline-1, average score was 14,67 point; on intervention, average score was increasing into 24,85 point; then on baseline-2, average score was increasing again into 27 point. Based on the above result it can be concluded that the building block game has an positive effect to the ability of social interaction of child with autism in second grade at SD Al Firdaus Surakarta in the year of 2018/2019.
\end{abstract}

Keywords: Building Block, The Ability Of Social Interaction, Autism

\section{Research Background}

A person must be able to make relations or interactions with other people as social beings, because in a community life someone will need each other. That need can lead to a process of social interaction. Walgito (2003: 65) says social interaction is a relationship between individuals one with another individual. Individual one can influence another individual or vice versa, so that it can be concluded that social interaction plays an important role, especially for a child as a provision in carrying out community life.

Peeter (2004) argues of Retained Earnings general development of social interaction children aged 4 years more focused on peers than adults, are very interested in a relationship of friendship, the behavior of a fight, mocked by peers is common, and can switch roles (role play) from the leader's role to the role of followers when playing with peers.

* Corresponding author: Tri Nuraini

trinuraini@student.uns.ac.id

Published online at http://IJDS.ub.ac.id/2019- 1

Copyright $\odot 2019$ PSLD UB Publishing. All Rights Reserved
Hasdianah (2013) argues that the development of social interactions in autistic children is different from children in general. Autistic children have the characteristics of social interaction shown by not wanting to look into the eye, being called not turning around, not wanting to play with their peers, playing alone, and having no empathy in the social environment. Carpenter (2003) also argues that in playing activities autistic children have difficulty establishing social relations with their friends as indicated by disinterest in an activity of others, having no interest in other people or peers, withdrawing, not trying to attract attention other people, do not realize the presence of others and also prefer activities solitary.

The ability of social interaction of autistic children can be improved through several efforts, among others, in the research of Rahmawati and Hardiani (2012), found the results that the method of Applied Behavior Analysis (ABA) affects the ability to socialize and interact with autistic children. Mawardah and Ainin (2014) in his study find result that the method can improve the ability to play the role of social interaction of children with autism. The treatment was carried out for 15 sessions with the results of autistic children showing increased eye contact, facial expressions, not refusing to be 
hugged, looking when called, crying or laughing because of being interested in toys and not playing with objects that were not toys.

The game can function as therapy or counseling to help children socialize and develop ego strength. Children also have the opportunity to expand their social interaction skills (Masnipal, 2013). The game can be divided into four types, namely functional games, symbolic games, game with rules, and constructive games. The games most often played by children are constructive games. Constructive play a game using the materials prepared in accordance creativity of children, so that it becomes a masterpiece, one of which is the building block game (pieces beam).

Building block is a constructional game that refers to the process of building, forming, and creative modification of building structures that already exist three-dimensional objects or sets of objects (Miller \& Boyd, 1970). Based on preliminary studies conducted by researchers at SD Al Firdaus Surakarta, there are currently autistic children who experience difficulties in social interaction with peers and other people. The problem of social interaction is shown by the characteristics of children who prefer to be alone, cool to play alone rather than interacting with friends, lack of eye contact, no social smile, refusing to be hugged and loved, and lacking empathy. Communication carried out by the child is only limited to non verbal communication.

\section{Research Methodology}

The design used in this study is experimental with a single subject or can also be called single subject research. Research experiments with a single subject focusing on an individual or several individuals. Measurement of variables in a single subject design is repeated over a period of time. Single subject design is carried out to investigate changes in behavior of a person arising as a result of treatment (Darmadi, 2014). The subjects used in this study were 8-year-old male autistic students. The single research design design that will be used in this study is the ABA design. The ABA design requires that a behavior be examined during the base control period (A1), during the treatment period (B), then examined again during the second base period (A2) after successful experimental treatment (Cozby, 2009).
The data collection method used in this study was observation. Observation is systematic observation and recording of symptoms that appear on the object of research (Sujarweni, 2014). Dimyati (2013) also states that observation is a method of collecting research data through observation of the object under study. Grids of observations in this study consist of 4 indicators, namely social approaches, sharing interests, responding when called, and making friends.

This study will measure the frequency of the ability of social interaction of autistic children in baseline - 1 (A1), intervention phase (B), and baseline -2 (A2). Measurements were made by recording the frequency of reciprocal behavior of children playing in 30 minutes each session using an observation instrument. Baseline A1 was done for 3 times, intervention B was carried out approximately 7 times, and baseline A2 was carried out for 3 times.

Table 1. Recapitulation of data on frequency observation of the ability of autistic subjects

\begin{tabular}{|c|c|c|}
\hline $\mathrm{n}^{\text {Sessio }}$ & Date & $\begin{array}{l}\text { Frequenc } \\
\mathrm{y}\end{array}$ \\
\hline 1 & $\begin{array}{r}\text { Marc } \\
\text { h 18, } 2019\end{array}$ & 14 \\
\hline 2 & $\begin{array}{r}\text { Marc } \\
\text { h 19, } 2019\end{array}$ & 15 \\
\hline 3 & $\begin{array}{r}\text { Marc } \\
\text { h 20, } 2019\end{array}$ & 15 \\
\hline 4 & $\begin{array}{r}\text { Marc } \\
\text { h 21, } 2019\end{array}$ & 23 \\
\hline 5 & $\begin{array}{r}\quad \text { Marc } \\
\text { h 22, } 2019 \\
\end{array}$ & 25 \\
\hline 6 & $\begin{array}{r}\quad \text { Marc } \\
\text { h 25, } 2019 \\
\end{array}$ & 23 \\
\hline 7 & $\begin{array}{r}\text { Marc } \\
\text { h 26, } 2019 \\
\end{array}$ & 25 \\
\hline 8 & $\begin{array}{r}\quad \text { Marc } \\
\text { h 27, } 2019 \\
\end{array}$ & 25 \\
\hline 9 & $\begin{array}{r}\quad \text { Marc } \\
\text { h 28, } 2019 \\
\end{array}$ & 27 \\
\hline 10 & $\begin{array}{r}\quad \text { Marc } \\
\text { h 29, } 2019 \\
\end{array}$ & 26 \\
\hline 11 & $\begin{array}{r}\text { April } \\
1,2019\end{array}$ & 27 \\
\hline 12 & $\begin{array}{r}\text { April } \\
2,2019 \\
\end{array}$ & 27 \\
\hline 13 & $\begin{array}{r}\text { April } \\
4,2019 \\
\end{array}$ & 27 \\
\hline
\end{tabular}

Sessions 1-3 are baseline-1 (A1) conditions. Sessions 4-10 are interventions, and 
sessions 11-13 are baseline-2 conditions (A2). Each session is measured in a span of 30 minutes.

The data analysis method used in this study is descriptive statistical analysis. Descriptive statistics in this study used visual analysis which is an analytical method that is often used in single subject research. Data analysis in this study was conducted by analyzing the behavior of autistic students during play activities, which was observed was the ability of social interaction to play reciprocally with others. Observation data in this study will be presented in graphical form to show each change in data in each session and show the frequency of social interaction behavior in the A1 baseline phase, intervention (B), and A2 baseline. Research with a single subject, data analysis is also done by analysis in conditions and between conditions (Sunanto, 2005) .

\section{Results \& Discussion}

\subsection{Results}

The study was conducted in three phases, namely the baseline-1 (A1), intervention, and baseline-2 (A2) phases. In each phase three observers conducted observations, namely observations in the form of frequency of social interactions in play. Data collection in the baseline-1 (A1) phase was carried out on 18.19, and March 20, 2019. Activities in the baseline-1 phase (A1) in the form of observations made in three sessions or until the data is stable. Each session is conducted for 30 minutes or during recess.

The next step is giving intervention. The intervention in this study was carried out for 7 sessions or after the data obtained was stable on the $21^{\text {st }}, 22^{\text {nd }}, 25^{\text {th }}, 26^{\text {th }}, 27^{\text {th }}, 28^{\text {th }}$, and $29^{\text {th }}$ of 2019. The activities in this phase were observations with the researchers giving treatment during playing breaks. The length of each session is the same as baseline-1 (A1) which is 30 minutes. The intervention provided is a building block game .

Table 2. Summary of Visual Analysis Results in ASR Subject Conditions

\begin{tabular}{|c|c|c|c|c|}
\hline & & Conditi & A & B \\
\hline $\mathrm{O}$ & on & 1 & & 2 \\
\hline & & $\begin{array}{l}\text { Length } \\
\text { dition }\end{array}$ & 3 & 7 \\
\hline
\end{tabular}

Table 3. Summary of Analysis Results Between ASR Subject Conditions

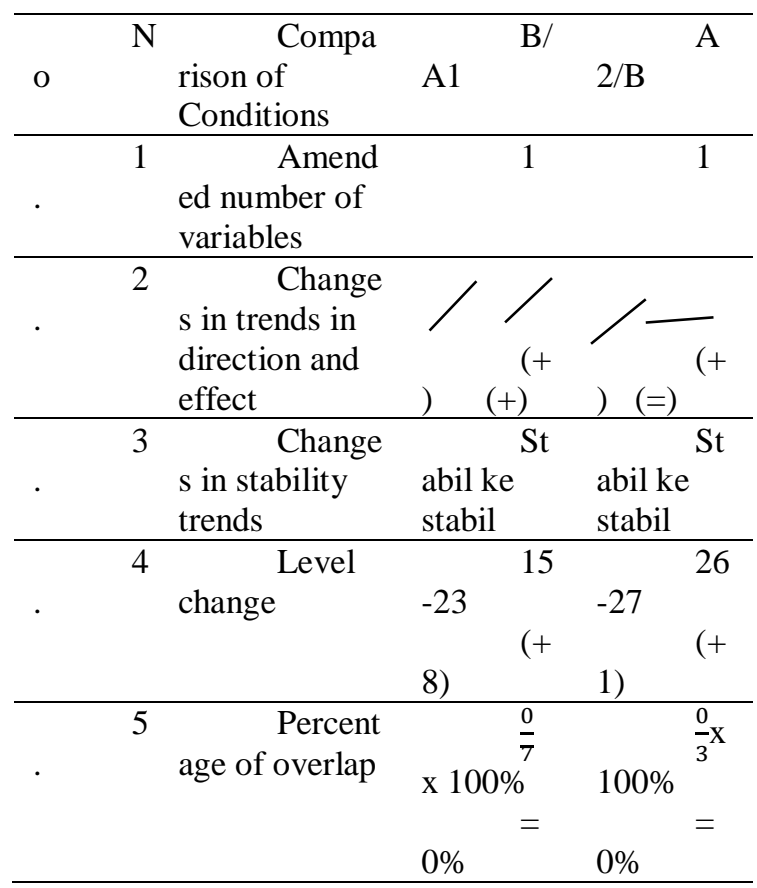

The instructions given are related to the way the subject is interact with peers and other people. The final stage is conducting baseline-2 measurements (A2). Baseline-2 (A2) is the last phase in this study, namely the phase after A intervention and is a repetition of the baseline-1 phase (A1). Activities carried out in the 2nd 3 baseline phase (A2) is the same as at baseline- 1 (A1) that is observation of social interaction in 
playing ASR subjects after being given an intervention. 2nd baseline activity (A2) aims to measure the behavior of the subject after being given an intervention and ensuring the effectiveness of the building block game intervention on the ability to interact with sosi al in playing on the subject. Data retrieval in the baseline-2 phase (A2) was carried out on the 1, 2, and 4 April 2019. Each session was conducted for 30 minutes.

Table 2 describes the summary of the results of data analysis under the following conditions: (a) the length of conditions carried out under baseline-1 conditions (A1) are 3 sessions, in the intervention condition are 7 sessions, and in baseline- 2 conditions (A2) is 3 sessions, (b) direction tendency, it can be seen that the estimation of direction trends in the baseline phase -1 (A1) increases, in the intervention phase increases, and in the baseline2 (A2) phase is stable, (c) the results of the trend of stability in the condition of baseline-1 (A1) of $100 \%$ which means the data is stable. In the intervention condition the tendency for stability is $85.71 \%$ which means the data is stable. At baseline-2 (A2) conditions of $100 \%$, which means data is stable, (d) traces of data traces, it is known that the estimated trend of data traces is in the baseline-1 phase (A1) increases, in the intervention phase increases, and in the baseline phase -2 (A2) stable, (e) the level of stability and range, it can be seen that the level of stability and range of subjects in the baseline-1 (A1) phase of the data are stable with a range of 14-15. Intervention phase (B) the data obtained is stable with a frequency range of 23-27. Data obtained in the baseline-2 phase (A2) is stable with a frequency range of 27-27. The three phases show data stability. (f) the level of change, seen from the table, it can be seen that the level of change at baseline-1 (A1) improves with the level of change of +1 , that is, the ability of the subject's social interaction has increased, in the intervention phase it improves with the level of change +4 , namely the ability of social interaction in play has increased and in the baseline-2 phase (A2) there is no increase with the level of change $=0$.

Explanation of table 3 above can be summarized as follows: (a) The number of variables changed from baseline-1 (A1) to intervention (B) and baseline-2 phases (A2), namely the ability of social interaction in playing reciprocally, (b ) changes in direction trends from baseline- 1 conditions (A1) to intervention is increasing, and from intervention to baseline 2 (A2) is stable, (c) change in the tendency for stability between baseline-1 (A1) to intervention is stable to stable, from intervention to baseline2 (A2) also stable to stable, (d) change in level, from intervention phase (B) to baseline-1 (A1) is increased. Changes in the baseline-2 (A2) to intervention (B) level are increasing. (e) percentage overlap, from condition B to condition A1 is $0 \%$. The percentage overlap condition A2 to B is also $0 \%$. These results indicate that building block play has a positive effect on the ability of social interaction of autistic children in class II at SD Firdaus Surakarta in 2018/2019.

\subsection{Discussion}

Based on the results of the research that has been done, it can be seen that building block games have a positive effect on the ability of social interaction of autistic children in class II at SD Al Firdaus Surakarta in 2018/2019. This result is in line with Hasdianah's theory (2013) that play is an effort to help autistic children improve their social interaction skills. Through the game children will be given the opportunity to develop their social skills, recognize and learn various things about their lives, practice courage and foster confidence.

The results of this study are in line with the opinion of Ismail (2006) that building blocks provide benefits for children's social development. This means that through building block games autistic children will gain experience in socializing with their peers. In addition, autistic children will learn about property rights, share toys, and use toys in turns through shared assignments. So that if you are accustomed to playing with friends, you will be able to improve the ability of social interaction in autistic children through their participation in play activities.

The reason for the researchers was also reinforced by the results of Volkenburg (2015) which stated that building block games proved effective in improving the language and social skills of autistic children. The results of this study are in line because building block games make autistic students develop their imagination and creativity. Imagination and creativity can be channeled through activities to create a building from beams with friends, so that the confidence in autistic children grows to interact with other 
children. Furthermore, this study uses a building block because building block is one of the effective tools to enhance the ability of social interaction and reduce the pattern of solitary play on autistic subjects.

The advantage in conducting research using building block games is that it can influence the ability of social interaction, especially in playing activities on autism. In addition, there has never been a previous study of the influence of building block games on the ability of social interaction in autistic children. This is because building block games provide opportunities for children to develop their creativity, language skills, skills, and physical body through the participation of children in joint play activities. Autistic students who previously lacked interaction in play such as approaching the teacher/friend, looking into the eyes of the teacher, showing activities, sharing toys and waiting their turn with the building block game students showed an increase in the ability of social interaction. In addition, there has never been a previous study of the influence of building block games on the ability of social interaction of autistic children. As for the lack of the application of building block games to children, the space and blocks used are still limited. The implication is that children are not able to maximize their ability to do elaboration in the form of buildings they make.

\section{Conclusion}

Based on the results of data analysis and discussion that has been described, it can be concluded that building block games have a positive influence on the ability of social interaction of autistic children in class II at SD Firdaus Surakarta in 2018/2019. Suggestions that can be given are:

\section{For Teachers}

a. Building block games can be used as an option to improve the ability of social interaction in playing with friends in autistic students.

b. The building block game should be given continuously so that it becomes a habit that really helps improve the ability of the subject's social interaction in playing with friends.

2. For Students

Students are expected to be able to maintain the application of the rules of building block games when playing together with their friends.

3 . For other researchers

a. This research is still limited to autistic class II subjects with passive interaction problems, so it is expected that further research will develop the application of building block games to overcome other behavioral problems in different subjects and classes.

\section{References}

Spectrum Disorder: Guedilines \& Criteria Exemplars. Retrieved from https://depts.washington.edu $>$ dbpends, date Desember 20, 2018.

Cozby, P.C. (2009). Methodes In Behavioral Research. Edisi 9. Yogyakarta: Pustaka Pelajar.

Darmadi, H. (2014). Metode Penelitian Pendidikan dan Sosial. Bandung: Alfabeta.

Dimyati, J. (2013). Metodologi Penelitian Pendidikan dan Aplikasinya Pada Pendidikan Anak Usia Dini (PAUD). Jakarta: Prenadamedia.

Hasdianah. (2013). Autis Pada Anak Pencegahan, Perawatan, dan Pengobatan. Yogyakarta: Nuha Medika.

Ismail, A. (2006). Education Games Menjadi Cerdas dan Ceria Dengan Permainan Edukatif. Yogyakarta: Pilar Media.

Masnipal. (2013). Siap Menjadi Guru dan Pengelola PAUD Profesional. Jakarta: Gramedia.

Mawardah, V. \& Ainin, K. (2014). Interaksi Sosial Anak Autis Dengan Metode Bermain Peran di SLB. Jurnal Pendidikan Khusus. (Online),

https://jurnalmahasiswa.unesa.ac.id/index.php/j urnal-pendidikan-

khusus/article/download/6338/7172, date Desember 19, 2018.

Miller, W.R. \& Boyd, G. (1970). Teaching Elementary Industrial Arts. South Holland, Illinois: The Goodheart-Wilcox Company.

Peeter, T. (2004). Panduan Autisme Terlengkap Hubungan Antara Pengetahuan Teoritis \& Intervensi Pendidikan Bagi Penyandang Autis. Jakarta: PT. Dian Rakyat. 
Sujarweni. (2014). Metodologi Penelitian. Yogyakarta: Pustaka Baru Press.

Rahmawati, S. \& Hardiani, R.S. (2012). Pengaruh Metode ABA: Kemampuan Bersosialisasi terhadap Kemampuan Interaksi Sosial Anak Autis. (Online), https://media.neliti.com/media/publications/107 104-ID-metode-aba-applied-behaviouranalysis-ke.pdf, date Desember 28, 2018.

Sunanto, J., Takeuchi, K. \& Nakata, H. (2005). Penelitian dengan Subjek Tunggal. Bandung: UPI Press.
Walgito, B. (2003). Psikologi Sosial (Suatu Pengantar). Yogyakarta: Andi.

Volkenburg, V. (2015). Reaching Children with Autism Spectrum Disorders Using Creative Dramatic: The Building Blocks Model. International Journal Of Education .(Online), 43 (2)

https://www.southernearlychildhood.org/upload /pdf/Dimensions_Vol43_2_VanVolkenburg_1. pdf, date Desember 19, 2018. 